the Central Hall. The several sections of the Congress are concerned with various phases of chemical engineering, as follows : $(a)$ ferrous metals in chemical plant construction; (b) refractories, rubber, plastics, and other materials in chemical plant construction; (c) separation ; $(d)$ size reduction, grading and mixing; electrolysis, etc.; (e) destructive distillation; $(f)$ treatment and disposal of effluents and waste materials ; lubrication ; $(g)$ high-pressure reactions and high vacua; $(h)$ heat exchange; $(j)$ education and training; $(k)$ statistics ; administration ; safety and welfare ; $(l)$ trend of development ; $(m)$ general aspects. Papers are being presented from Great Britain, Holland, the United States of America, Canada, Japan, Sweden, Austria, Germany, Poland, Russia, Denmark, Hungary and Switzerland ; about one hundred and twenty titles are given in the provisional time table. The president is Viscount Leverhulme. Chairmen of committees are as follows : organising, Sir David Milne-Watson; technical, Mr. W. A. S. Calder; hospitality, Sir Alexander Gibb; finance, Mr. J. Davidson Pratt; publicity, Dr. E. W. Smith. The general secretary is Mr. M. W. Burt, and the international secretary is $\mathrm{Mr}$. C. $\mathrm{H}$. Gray. Communications from Great Britain should be addressed to the Congress Office, 56 Victoria Street, London, S.W.1, and those from other countries should be addressed to the Office of the International Secretary, 36 Kingsway, London, W.C.2. Further announcements will be made in due course.

\section{Tracing the Dawn of Life}

IN 1917, there was inaugurated at the Cawthron Institute of Seientific Research, Nelson, New Zealand, an annual lecture to commemorate the generosity and foresight of the founder of the Institute, Thomas Cawthron. Each year since then, with the exception of 1931, the Cawthron Lecture has given a distinguished investigator an opportunity of setting before the public the results of progress in some particular branch of knowledge. The lecturer of 1935 was Dr. R. J. Tillyard, his subject "Tracing the Dawn of Life Further Backwards". In following the conditions of life in geological epochs from the present to the earliest times, he discussed briefly the outstanding products of each age. The climax of his story was the statement that in Pre-Cambrian rocks, belonging to the Middle Proterozoic series of Tree Gully near Adelaide, the late Prof. David and he had discovered remains which he had described (in a paper shortly to be published) as belonging to a new class of Arthropods, differing from all other arthropods in having the segments of the head freely articulated.

\section{The Warburg Institute}

IN May 1934 the Warburg Society was formed with the object of establishing the Warburg Institute, formerly of Hamburg, in England. The first annual report since this movement took place shows that the transference has been successfully accomplished, and that in its new rooms in Thames House, London, the Institute has been able to resume most of its old activities and to feel its way towards new ones. The
Institute has three links with the public--its library, its series of lectures, and its publications. The transference of the first was completed on June 28, 1934, and since then the number of serious and research readers has steadily increased. Several lecture courses on various aspects of the history of art were given by English, German and French scholars, including a three-weeks' course on palæography by Prof. R. Salomon of Hamburg. The report makes grateful acknowledgment of the help given by English patrons.

\section{Congress of Refrigeration}

THE seventh International Congress of Refrigeration will be held at The Hague and Amsterdam on June 16-27. The Congress will be divided into four sections : (1) Scientific (physics, chemistry, thermo. dynamics, units, biology and medicine); (2) Refrigerating Machines and Materials (air-conditioning, insulating materials, refrigerating plants and testing mothods); (3) General Applications of Refrigeration (food and perishable products, agricultural industries, ice industries, chemical and rare gas industries, low temperatures); (4) Refrigerated Transport, etc. (land and water transport, legislation, education and propaganda, general economics and statistics). Among the visits arranged is one to the Kamerlingh Onnes Laboratory at Leyden, where lectures and demonstrations of eryogenic work will be given by Prof. H. W. Keesom and Prof. W. J. de Haas. Further information can be obtained from the Organisation Office, 107 Stolbergloan, The Hague.

\section{Announcements}

THE following medals will be awarded at the annual corporate meeting of the Institution of Chemical Engineers on March 6: Moulton Medal, for the paper on "The Evaporation of Water from Plane and Cylindrical Surfaces", to R. W. Powell and Dr. Ezer Griffiths ; Osborne Reynolds Medal, for meritorious service in the advancement of the Institution, to F. A. Greene ; and the William Macnab Medal (first award), for the best set of answers submitted in the associate-membership examination in 1935 , to D. K. Moore.

LORD RAYLEIGH has been elected chairman of the governing body of the Imperial College of Science and Technology in succession to the Marquess of Linlithgow, who has resigned on taking up his appointment as Viceroy of India.

Ar a meeting of the executive of the Parliamentary Science Committee held on February 6 at the House of Commons, under the chairmanship of Sir Arnold Wilson, Mr. Alan Chorlton, M.P. for Bury, was re-elected deputy-chairman of the Committe日; and Lord Melchett, Prof. Graham Kerr and Mr. Andrew McLaren were elected as additional parliamentary members of the executive.

AT a recent meeting, the Council of the Royal Asiatic Society conferred honorary membership upon Prof. Georges Coedes, of the Ecole Francaise 